\title{
Analysis of Motivation and How The Students Learn in Pandemic
}

\section{Analisis Motivasi Dan Cara Belajar Mahasiswa Di Masa Pandemi}

\author{
Wahyuddin Wahyuddin $^{1 *}$, Maharida Maharida ${ }^{1}$, Edi Jusriadi ${ }^{2}$, Syafaruddin Syafaruddin ${ }^{1}$ \\ ${ }^{1}$ Fakultas Keguruan dan IImu Pendidikan, Universitas Muhammadiyah Makassar Sulawesi Selatan, Indonesia, ${ }^{2}$ Fakultas \\ Ekonomi dan Bisnis, Universitas Muhammadiyah Makassar, Indonesia
}

The purpose of this study was to analyze in-depth the level of learning motivation and student learning, as well as the obstacles faced by students in online learning during the pandemic. Learning motivation has a very important role in improving the quality of the process and learning outcomes, if the student has high learning motivation, it can intensify learning activities, involvement, and student behavior. Apart from motivation, the learning method is also a determining factor in the learning process and outcomes. The learning method is an activity that is carried out in learning something in a particular learning situation. A student will have good learning outcomes if the learning method used is efficient and effective. During the pandemic, formal education activities, learning, and assessment are still ongoing and carried out online, but the implementation of learning also got many problems and obstacles faced by students so that motivation and learning are the factors that contribute to online learning during the pandemic. This type of research was qualitative descriptive which was conducted at the Universitas Muham-

OPEN ACCESS ISSN 25482254 (online) ISSN 20893833 (print)

Edited by:

Mahardika Darmawan Kusuma Wardana

Reviewed by:

Emy Pratiwi

${ }^{*}$ Correspondence: Wahyuddin Wahyuddin wahyu@unismuh.ac.id

Received: 11 Juni 2020

Accepted: 5 Agustus 2020

Published: 17 Agustus 2020

Citation:

Wahyuddin W, Maharida M, Jusriadi E and Syafaruddin S (2020) Analysis of Motivation and How The

Students Learn in Pandemic. PEDAGOGIA: Jurnal Pendidikan.

9:2. doi: 10.21070/pedagogia.v9i2.570 madiyah Makassar in March-May 2020. The total population is 19,810, the number of samples was through Slovin formula so the total was 724 people. The sampling technique was accidental sampling. Methods of data collection were questionnaires and then distributed via google forms. The data analysis technique was descriptive qualitative to describe the research variables. The results of the study conclude that there is quite a lot of learning obstacles faced by students during the pandemic, including inadequate learning facilities, inadequate networks, expensive, and learning condition at home which is not conducive, and lecturing schedules that are carried out by lecturers irregularly, but these obstacles are not that significant because student learning motivation is in the high category with indicators of desire and willingness to succeed, the need for learning, the expectation of student aspirations for the future, learn independently because of their wants, commit, have initiative, and have an optimistic attitude; In terms of learning methods, student learning methods are in a good category. The students have their way of learning: managing study time, repeating lesson materials, spending time reading books, articles, and references, and making summaries of the material that has been discussed.

Keywords: Learning Method, Learning Obstacles, Pandemic Period, and Learning Motivation

Tujuan penelitian ini adalah untuk menganalisis lebih jauh tentang tingkat motivasi belajar dan cara belajar mahasiswa, serta kendala yang dihadapi mahasiswa dalam pem- 
belajaran online di masa pandemi. Motivasi belajar memiliki peran yang sangat penting dalam meningkatkan kualitas proses dan hasil pembelajaran, ketika motivasi belajar mahasiswa tinggi, maka dapat menggiatkan aktivitas belajar, keterlibatan, dan perilaku mahasiswa tersebut. Selain motivasi, cara belajar juga merupakan factor penentu dalam proses dan hasil belajar. Cara belajar merupakan kegiatan yang dilakukan dalam mempelajari sesuatu dalam situasi belajar tertentu. Seorang mahasiswa akan mempunyai hasil belajar yang baik bila cara belajar yang digunakan efisien dan efektif. Dimasa pandemi aktivitas pendidikan formal, pembelajaran dan penilaian tetap berjalan dan dilaksanakan secara daring, namun pelaksnaan pembelajaran dari menuai banyak permasalahan dan kendala yang dihadapi mahasiswa sehingga motivasi dan cara belajar merupakan salah satu faktor yang memberi kontribusi dalam pembelajaran on line dimasa pandemi. Jenis penelitian ini adalah deskriptif kualitatif yang dilaksanakan di Universitas Muhammadiyah Makassar pada Bulan Maret-Mei Tahun 2020. Jumlah populasi sebanyak 19.810, penentuan jumlah sampel dengan rumus Slovin sehingga yang menjadi sampel sebanyak 724 orang. Teknik pengambilan sampel yaitu sampling aksidental. Metode pengumpulan data dengan menggunakan kusioner yang disebarkan melalui google forms. Teknik analisis data adalah deskriptif kualitatif untuk mendeskripsikan variabel penelitian. Hasil penelitian menyimpulkan kendala belajar yang dihadapi mahasiswa dalam masa pandemi cukup banyak diantaranya fasilitas belajar tidak memadai, jaringan tidak memadai, membutuhkan biaya yang mahal, suasana belajar di rumah yang tidak kondusif, dan jadwal kuliah dilakukan oleh dosen dengan tidak teratur, namun kendala tersebut tidak terlalu berarti karena motivasi belajar mahasiswa berada pada kategori tinggi dengan indikator hasrat dan keinginan ingin berhasil, adanya kebutuhan dalam belajar, adanya harapan cita-cita mahasiswa untuk masa depannya, belajar secara mandiri karena keinginannya sendiri, memiliki komitmen dalam belajar, memiliki inisiatif dalam belajar, dan memiliki sikap optimis dalam belajar; Dari segi cara belajar, cara belajar mahasiswa berada pada kategori baik. $m$ ahasiswa memiliki cara sendiri dalam belajar yaitu mengatur waktu belajar, mengulang bahan pelajaran, meluangkan waktu baca buku, artikel dan referensi, dan membuat ringkasan dari materi yang telah dibahas.

Keywords: Learning Method, Learning Obstacles, Pandemic Period, and Learning Motivation

\section{PENDAHULUAN}

Musibah penyebaran wabah virus yang bermula dari kota Wuhan di Tiongkok Akhir Tahun 2019 yang merupakan virus corona jenis baru (SARS-CoV-2) menyebar ke berbagai negara dan menyebabkan timbulnya penyakit COVID-19 hampir di seluruh negara di dunia. Sehingga pada Tangga 11 Maret 2020, WHO menetapkan COVID-19 sebagai pandemic Putri (2020) . Kondisi ini jelas tidak boleh diremehkan karena hanya ada beberapa penyakit saja sepanjang sejarah yang digolongkan sebagai pandemi. Dengan status pandemi saat ini juga terjadi di Indonesia otomatis menghentikan banyak kegiatan kehidupan publik mulai dari kegiatan kantor di pemerintahan, perusahaan, sekolah dan universitas ditutup, sekirat 7,5 juta mahasiswa dan 45 juta pelajar sekolah dasar dan menengah harus belajar dari rumah. begitu pula dengan pekerjaan di kantor pemerintah dan perusahaan, semua dialihkan dengan bekerja dari rumah (Work From Home (WFH)), Amindoni (2020). Untuk mencegah dan memutus mata rantai penyebaran virus tersebut, maka beberapa daerah sudah menerapkan pembatasan sosial berskala besar (PSBB) termasuk di Kota Makassar Sulawesi Selatan.

Dengan situasi pandemi saat ini sehingga pemerintah melalui Badan Nasional Penanggulangan Bencana telah mengeluarkan Surat Keputusan Status Keadaan Tertentu Darurat Bencana Wabah Penyakit Akibat Virus Corona di Indonesia yang berlaku sampai 29 Mei 2020, Putri (2020) . Sehingga berdasarkan hal tersbut, sekolah dan kampus diliburkan, kegiatan belajar tatap muka yang selama ini berjalan seperti biasanya harus diganti dengan pembelajaran dalam jaringan (on line), kegiatan pembimbingan akademik dan kegiatan ekstrakurikuler, dan 
kegiatan-kegiatan penunjang akademik seperti seminar, workshop, simposium, dan sebagainya semua di tunda dan atau dilaksanakan secara online dalam jaringan. Ujian akhir nasional tingkat pendidikan dasar dan menengah yang biasanya dilaksanakan tiap tahun, kini ditiadakan dan diganti dengan penetapan kelulusan dengan menggunakan nilai raport siswa.

Dalam aktivitas pendidikan formal, pembelajaran dan penilaian tetap harus berjalan karena kurikulum dan konten pembelajaran yang berjalan setiap semesternya telah diatur sedemikian hingga dan masing-masing memiliki target capaian dan standar kompetensi, sehingga jika pembelajaran dalam satu semester dihentikan, maka akan berdampak pada tidak tercapainya tujuan pembelajaran pada semester tersebut yang berpengaruh pada tidak tercapainya standar pembelajaran di setiap jenjang pendidikan. Dalam Undang-Undang Sisdiknas Nomor 20 Tahun 2003 menjelaskan bahwa pendidikan merupakan usaha sadar dan terencana untuk mewujudkan suasana belajar dan proses pembelajaran agar peserta didik secara aktif mengembangkan potensi dirinya untuk memiliki kekuatan spiritual keagamaan, pengendalian diri, kepribadian, kecerdasan, akhlak mulia, serta keterampilan yang diperlukan dirinya dan masyarakat.

Mengingat pendidikan adalah kebutuhan dasar setiap manusia khususnya bagi mereka yang berada pada jenjang penididikan formal, sehingga proses pembelajaran terus dilanjutkan untuk memenuhi standar proses pembelajaran sesuai dengan masing-masing tingkatan, sehingga dalam keadaan masa pendemi, proses belajar mengajar harus tetap dilaksanakan secara maksimal meskipun melalui jaringan. Untuk memastikan bahwa proses pembelajaran tetap berjalan secara maksimal, maka pemerintah telah melaksanakan berbagai upaya misalnya ditingkat sekolah dasar, dilakukan pembelajaran secara online melalui siaran Televisi Republik Indonesia (TVRI), sedangkan jenjang sekolah menengah pertama dan menengah atas di serahkan kepada masing-masing sekolah dan guru untuk tetap melaksanakan pembelajaran dengan memanfaatkan berbagai media seperti email, whats app, google meeting, zoom, dan media sosial lainnya. Upaya lain yang dilakukan pemerintah adalah dengan bekerjasama dengan pihak penyedia jaringan telekomunikasi untuk menjamin ketersediaan jaringan secara murah dan terjangkau sampai ke pelosok desa.

Di perguruan tinggi sendiri juga terjadi hal demikian, institusi pendidikan di seluruh dunia telah ditutup karena pandemi COVID-19 yang membahayakan kalender akademik. Sebagian besar lembaga pendidikan telah beralih ke platform pembelajaran online untuk menjaga agar kegiatan akademik tetap berjalan. Namun, pertanyaan tentang kesiapan, perancangan dan efektivitas e-learning masih belum dipahami dan beum siap dilaksanakan secara merata disetiap daerah, khususnya untuk negara berkembang seperti Indonesia, di mana kendala teknis seperti kesesuaian perangkat dan ketersediaan bandwidth merupakan tantangan serius. Di Universitas Muhammadiyah Makassar sendiri, proses pembelajaran, bimbingan proposal, bimbingan skripsi, bimbingan akademik dan non akademik, ujian proposal, dan ujian skripsi tetap terus berjalan meskipun dalam jaringan. Kegiatan pembelajaran tetap diklasanakan dalam jaringan dengan menggunakan berbagai media, baik media pembelajaran SPADA yang merupakan sistem pembelajaran yang disiapkan kampus, maupun media lain seperti zoom, whats app, google meeting, mailing liss, dan media lainnya. Dan untuk menunjang pelaksanaan pembelajaran secara online, maka Rektor Universitas Muhammadiyah Makassar telah memberi subsidi kota data sebesar Rp.250.000,- permahasiswa. Tetapi efektivitas program pembelajaran dalam jaringan tersebut tidak bisa disetarakan dengan interaksi pembelajaran langsung, hal tersebut karena perbedaan metode pembelajaran yang sebelumnya onair menjadi online, yang biasanya pembelajaran tatap muka secara langsung menjadi muka dalam tatap layar, dimana hal ini memunculkan peluang dan tantangan baru di dunia pendidikan untuk terus dikembangkan.

Namun kenyataan yang terjadi, meskipun proses pembelajaran tetap berjalan seperti biasa melalui jaringan, namun banyak hal yang menjadi kehawatiran dan kendalan dalam proses pembelajaran secara online tersebut. Beberapa permasalahan yang muncul yang diperoleh baik dari mahasiswa maupun dosen yaitu diantaranya : 1) proses pembelajaran secara online tidak dapat berjalan secara maksimal karena penyampaian materi melalaui media online tidak seefektif dengan tatap muka secara langsung, khususnya mata kuliah yang membutuhkan penjelasan dan penurunan rumus-rumus yang rumit seperti matematika, kalkulus, statistika, dan sebagainya; 2) tidak tersedianya jaringan yang memadai, khususnya bagi mahasiswa yang tinggal di pedalaman, sehingga untuk mengakses materi pembelajaran atau mengikti pembelajaran 
online tidak maksimal; 3) banyaknya keluhan dari mahasiswa karena merasa bahwa pembelajaran dalam jaringan memberatkan mahasiswa dengan kebanyakan tugas yang diberikan oleh dosen; 4) banyaknya keluhan tentang mahalnya biaya yang harus dikeluarkan mahasiswa untuk menyiapkan kuota data dalam mengikuti pembelajaran secara online; 5) pembelajaran dalam setiap pertmuannya terkadang tidak tuntas karena dibatasi ruang dan waktu sehingga banyak pertanyaan-pertanyaan mahasiswa yang tidak bisa terjawab; 6) fasilitas pembelajaran dalam jaringan terbatas, khususnya bagi mereka yang golongan ekonomi bawah yang tidak memiliki fasilitas seperti laptop dan hand phone android; 7) keterbatsan tenaga pendidikan dalam mengadopsi metode-metode pembelajaran jarak jauh yang selama ini jarang dipraktekkan; dan 8) keterbatasan orang tua mahasiswa untuk menyiapkan fasilitas belajar, khususnya suasana belajar yang berlangsung dirumah masing-masing.

Lalu bagaiman memastikan bahwa capaian pembelajaran mata kuliah dalam satu semseter dimasa pandemi ini bisa tercapai jika dihadapkan dengan berbagai permasalahan. Banyak faktor yang dapat berpengaruh terhadap prestasi mahasiswa salah satunya adalah faktor internal dan eksternal mahasiswa. Faktor internal merupakan faktor dalam diri mahasiswa seperti intelegensi, motivasi belajar, minat siswa, sikap dan persepsi mahasiswa terhadap guru, sedangkan faktor eksternal merupakan faktor pendukung yang berasal dari luar diri mahasiswa seperti pendidikan dan pekerjaan orang tua, lingkungan, dan sarana prasarana belajar, Walgito (2014). Salah satu faktor yang berasal dari dalam diri individu (internal) adalah motivasi belajar. Motivasi untuk belajar sangat penting karena dengan motivasi dapat meningkatkan interaksi dengan siswa, meningkatkan pengetahuan tingkat tinggi bagi siswa, serta mendukung unsurunsur lain dari lingkungan belajar, (Hynd et al., 2000). Menurut Mc. Donald Hamalik (2011), motivasi adalah perubahan energi dalam diri seseorang yang ditandai dengan timbulnya reaksi untuk mencapai tujuan. Sedangkan menurut Sardiman (2010) dalam kegiatan belajar motivasi merupakan keseluruhan daya penggerak siswa yang dapat menimbulkan kegiatan belajar, sehingga tujuan yang dikehendaki oleh subjek belajar itu dapat tercapai. Sedangkan menurut Uno (2011) hakikat motivasi belajar adalah dorongan internal dan eksternal pada siswa yang sedang belajar untuk mengadakan perubahan tingkah laku, pada umumnya dengan beberapa indikator atau unsur yang mendukung. Sehingga dari berbagai pendapat tersebut, dapat disimpulkan bahwa motivasi belajar adalah suatu faktor penggerak yang timbul dalam diri siswa yang terus mendorong siswa untuk belajar sampai mencapi tujuan pembelajaran yang diinginkan.

Lebih lanjut, Uno (2011) juga menyebutkan indikator motivasi belajar dapat diklasifikasikan sebagai berikut: 1) adanya hasrat dan keinginan berhasil; 2) adanya dorongan dan kebutuhan dalam belajar; 3) adanya harapan atau cita-cita masa depan; 4) adanya penghargaan dalam belajar; 5) adanya kegiatan yang menarik dalam belajar; dan 6) adanya lingkungan belajar yang kondusif, sehingga memungkinkan seorang siswa dapat belajar dengan baik. Di bidang pendidikan, motivasi telah diidentifikasi sebagai faktor penting yang mempengaruhi pembelajaran. Lim (2014) Studi sebelumnya menunjukkan bahwa motivasi pelajar berhubungan dengan berbagai konsekuensi pembelajaran yang penting seperti ketekunan, retensi, pencapaian dan kepuasan belajar. Penelitian tentang prestasi akademik siswa juga telah menekankan pentingnya mempertimbangkan komponen motivasi yang telah dikaitkan secara konsisten seperti pembelajaran mandiri, keinginan untuk mengerjakan tugas-tugas kelas, dan kecemasan. Dari berbagai bukti penelitian menunjukkan bahwa motivasi harus ditanggapi dengan serius di lingkungan pembelajaran.

Motivasi belajar memiliki peran yang sangat penting dalam meningkatkan kualitas proses dan hasil pembelajaran. Motivasi belajar yang tinggi dapat menggiatkan aktivitas belajar mahasiswa, mahasiswa yang memiliki motivasi tinggi dapat terlihat dari perilaku mahasiswa tersebut. Sugihartono et al. (2007) menjelaskan bahwa siswa yang memiliki motivasi belajar tingi dapat meningkatkan kualitas keterlibatan siswa dalam belajar yang sangat tinggi pula, dengan motivasi belajar yang dimiliki siswa akan memunculkan perasaan dan keterlibatan afektif siswa yang tinggi dalam belajar, adanya upaya siswa untuk senantiasa memelihara atau menjaga agar senantiasa memiliki motivasi belajar tinggi.

Terdapat beberapa hasil penelitian yang menjelaskan pengaruh motivasi belajar terhadap hasil belajar, diantanranya : 1) Cao and Meng (2019) dengan hasil penelitian bahwa motivasi belajar ditemukan dapat memoderasi hubungan extraversion dengan prestasi bahasa Inggris 
dan pengetahuan global, dimana siswa yang memiliki motivasi belajar tinggi memiliki prestasi bahasa Inggris dan pengetahuan global lebih tinggi dibanding dengan siswa dengan motivasi belajar yang rendah; 2) Tanaka (2013) dengan hasil penelitian bahwa motivasi intrinsik secara signifikan memprediksi kemampuan kanji yang lebih tinggi; 3) Wen and Piao (2020) dengan hasil penelitian bahwa faktor motivasi mendukung pembelajaran bahasa Cina mencakup tiga dimensi yaitu strategi pengaturan diri sendiri, keinginan gigih peserta didik untuk belajar dalam penilaian bahasa Cina, dan gaya belajar disesuaikan dengan tujuan belajar mereka; 4) dan KuanChungChen and Syh-JongJang (2010) bahwa motivasi intrinsik, motivasi ekstrinsik, dan motivasi adalah konstruksi yang khas, dan beroengaruh langsung dan tidak langsung dalam memberikan dampak pada peningkatan hasil belajar.

Belajar merupakan suatu proses aktivitas mental kejiwaan manusia. Dampak perubahan setelah belajar ditandai dengan adanya perubahan dari perilaku individu yang belajar baik mencakup proses perubahan kognitif, keterampilan ataupun sikap. Oleh karena itu untuk mencapai tujuan belajar tersebut, maka perlu cara atau metode belajar. Faktor lain yang berpengaruh terhadap keberhasilan proses dan hasil belajar adalah cara belajar siswa. Hamalik (2011) mengemukakan bahwa cara belajar adalah "kegiatan-kegiatan yang dilakukan dalam mempelajari sesuatu, artinya kegiatan-kegiatan yang seharusnya dilakukan dalam situasi belajar tertentu. Cara belajar adalah kebiasaan belajar atau cara belajar yang mempengaruhi belajar meliputi; mengulangi bahan pelajaran, membaca dan membuat catatan, kosentrasi, mengerjakan tugas, cara mengatur waktu belajar. Seorang siswa akan mempunyai hasil belajar yang baik bila cara belajar yang digunakan cukup efisien, cara belajar yang efektif setidak-tidaknya ditentukan oleh keteraturan, disiplin, dan semangat, konsentrasi, pengaturan waktu, dan cara-cara belajar yang dilakukan siswa.

Weck dan Master Collins (2017) mengatakan bahwa cara siswa belajar dipengaruhi oleh teori kecerdasan diri mereka. Seorang siswa yang menganut teori entitas kecerdasan percaya bahwa kecerdasan itu tetap. Dengan kata lain, mereka menganggap bawa siswa masing-masing dilahirkan dengan IQ tinggi atau IQ rendah. Jika siswa harus berusaha keras dalam pembelajaran, maka itu membuktikan bahwa siswa tersebut tidak terlalu pintar. Penekanannya kemudian menjadi terlihat cerdas, bagaimanapun caranya. Di sisi lain, siswa yang berlangganan teori kecerdasan in-cremental percaya bahwa mereka dapat belajar bagaimana menjadi lebih baik belajar, sehingga memotivasi mereka untuk menjadi pembelajar mandiri. Bukti empiris tentang pentingnya cara belajar dalam meningkatkan hasil belajar dikemukakan oleh Hidayati (2011) dengan kesimpulan bahwa terdapat pengaruh positif dan signifikan cara belajar terhadap prestasi belajar siswa;

Berdasarkan kajian sebelumnya pada latar belakang yang menguraikan bahwa motivasi dan cara belajar merupan dua variabel yang memiliki kontribusi penting dalam meningkatkan kualitas proses pembelajaran yang dapat berpengaruh terhadap peningkatan hasil belajar, maka penelitian ini bertujuan untuk mengetahui bagaimana tingkat motivasi dan cara belajar mahasiswa di masa pandemi serta kendala apa yang dihadapi mahasiswa selama belajar online di masa pandemi. Adapun pertanyaan penelitian yaitu :1) Bagaimana tingkat motivasi belajar mahasiswa di masa pandemi;2) Bagaimana tingkat motivasi belajar mahasiswa di masa pandemi; 3) Kendala-kendala apa yang dihadapi siswa dalam pembelajaran online di masa pandemi.

\section{METODE}

Jenis penelitian ini adalah penelitian survey degan pendekatan deskriptif kualitatif yang digunakan untuk menemukan fakta pengetahuan atau teori terhadap penelitian pada satu waktu tertentu, Mukhtar (2013) . Penelitian ini terdiri dari tiga variable yaitu variable motivasi dengan indicator hasrat berhasil, adanya dorongan, harapan, keinginannya sendiri, komitmen, inisiatif, dan sikap optimis; Variabel cara belajar dengan indikator mengatur waktu belajar, mengulang bahan pelajaran, meluangkan waktu membaca buku, artikel, dan referensi, serta membuat ringkasan materi; dan variable kendala belajar dengan indikator fasilitas belajar, jaringan, biaya, suasana belajar, dan jadwal kuliah . Penelitian ini dilaksanakan di Universitas Muhammadiyah 
Makassar pada Bulan Maret-Mei 2020 dengan jumlah populasi mahasiswa sebanyak 19.810 yang terdaftar pada semester genap 2019-2020, penentuan jumlah sampel dengan rumus Slovin bahwasampel minimal $=\frac{N}{1+N(e)}$ dari anggota populasi (Umar, 2001), sehingga diperoleh jumlah sampel minimal 392 orang, namun dalam penelitian ini yang bersedia memberi respondes sebanyak 724 orang, sehingga yang menjadi sampel sebanyak 724 orang. Teknik pengambilan yang digunakan yaitu sampel kebetulan atau sampling aksidental, penggunaan metode sampling tersebut dengan pertimbangan bahwa yang menjadi sampel adalah mahasiswa yang bersedia memberi respon pengisian kusioner dengan. Metode pengumpulan data dilakukan dengan menggunakan kusioner yang sebarkan melalaui google forms. Teknik analisis data yang digunakan adalah deskriptif kualitatif untuk mendeskripsikan masing-masing variabel penelitian. Dasar interpretasi kategori hasil penelitian berdasarkan Jr et al. (2017) dengan sebaran sebagai berikut.Tabel 1

[Table 1 about here.]

\section{HASIL DAN PEMBAHASAN}

Hasil penelitian ini diuraikan dengan beberapan poin yang terdiri atas karakteristik responden, deskriptif masing-masing variabel, dan pembahasan yang diuraiakan sebagai berikut. Kerakteristik responden dalam penelitian ini diuraikan sebagai berikut:Tabel 2

[Table 2 about here.]

Deskripsi variabel hasil penelitian sebagai berikut:Tabel 3, 4 and 5

[Table 3 about here.]

[Table 4 about here.]

[Table 5 about here.]

Motivasi belajar mahasiswa berada pada kategori tinggi dengan nilai mean, 4,11. Motivasi mahasiswa dilihat dari indikator hasrat dan keinginan ingin berhasil, adanya dorongan dan kebutuhan dalam belajar, adanya harapan atau cita-cita mahasiswa untuk masa depannya, mahasiswa belajar secara mandiri karena keinginannya sendiri, memiliki komitmen dalam belajar, memiliki inisiatif dalam belajar, dan memiliki sikap optimis dalam belajar.

Meskipun banyak kendala yang dihadapi mahasiswa dalam belajar online di masa pandemi, namun motivasi mahasiswa untuk belajar cukup tinggi. Hal ini memberikan makna positif yang berarti bahwa kendati proses pembelajaran dilaksanakan secara online yang dibatasi oleh ruang dan waktu, namun kendala-kendala yang dihadapi tersebut bisa diminimalisir dengan tingginya semangat mahasiswa belajar secara mandiri. Dari ketujuh indikator motivasi belajar, indikator ketiga tentang adanya harapan atau cita-cita masa depan mahasiswa merupakan indikator yang memberi kontribusi besar dalam pembentukan motivasi mahasiswa dalam belajar. Dengan dasar adanya harapan atau cita-cita masa depan sehingga mahasiswa terus belajar secara tekun dan maksimal meskipun dalam masa pandemi seperti ini. Hal ini sesuai dengan yang diungkapkan Uno (2011) bahwa belajar dengan harapan dan cita-cita, maka dapat menumbuhkan motivasi belajar dalam diri mahasiswa sehingga mereka mengalami perubahan tingkah laku yang lebih baik dalam belajar.

Purwanto (2012) juga menjelaskan tentang pentingnya motivasi belajar yaitu mendorong manusia untuk berbuat baik, sebagai penggerak atau memberikan energi kepada seseorang untuk melakukan suatu tugas, menetukan arah perbuatan kearah perwujudan sesuatu tujuan atau cita-cita, serta memperjelas hal yang harus dilakukan guna mencapai tujuan yang diharapkan. Motivasi dapat menjadi awal pembelajaran mandiri. Sebagai contoh, jika seorang mahasiswa tertarik pada suatu subjek, maka mahasiswa itu lebih mungkin untuk memulai tugas 
mempelajarinya. Motivasi mempengaruhi proses belajar mandiri. Dengan kata lain, jika seorang mahasiswa termotivasi, mahasiswa cenderung menghabiskan lebih banyak waktu belajar. Motivasi juga bisa menjadi hasil dari belajar mandiri. Ketika seorang mahasiswa berhasil menyelesaikan tugas, hasilnya adalah lebih percaya diri dalam belajar, kemampuan yang dimiliki lebih banyak, serta memunculkan kegembiraan tentang belajar dalam dirinya. Dalam hal cara belajar, selain belajar tatap muka secara online, mahasiswa juga memiliki cara belajar sendiri. Cara belajar mahasiswa dimasa pandemi berada pada kategori baik dengan nilai mean, 3,51. Mahasiswa memiliki beberapa cara sendiri dalam belajar yaitu mengatur waktu belajar mandiri, mengulang bahan pelajaran, meluangkan waktu baca buku, meluangkan waktu membaca artikel dan referensi secara online, dan membuat ringkasan/khtisar dari materi yang telah dibahas oleh dosen.

Cara belajar mandiri yang paling banyak dilakukan mahasiswa di masa pandemi ini yaitu mahasiswa mengatur waktu belajar mandiri. Hal ini memberi hasil positif karena dengan mengatur waktu belajar secara mandiri dapat menunjang pencapaian tujuan pembelajaran, yang berarti bahwa jika sifat keteraturan belajar telah benar dihayati seorang mahasiswa, maka akan menjadi kebiasaan mahasisiswa tersebut dalam perbuatannya serta akan mempengaruhi jalan pikirannya, sehingga keteraturan dalam belajar tercermin dalam tindakan mahasiswa setiap harinya. Hal lain yang menggambarkan cara belajar mahasiswa yaitu dengan mengulang bahan pelajaran, meluangkan waktu baca buku, meluangkan waktu membaca artikel dan referensi secara online, dan membuat ringkasan/khtisar dari materi yang telah dibahas oleh dosen. Dimana semua indikator tersebut berada pada kategori tinggi. Hasil penelitian ini didukung oleh pendapat Djamarah and Zain (2010) yang mengemukakan cara belajar yang efisien adalah belajar mengguanakan fasilitas dan perabot belajar yang cukup, mengatur waktu belajar, mengulangi bahan pelajaran, menghafal bahan pelajaran, membaca buku, membuat ringkasan, mengerjakan tugas, dan memanfaatkan perpustakaan.

Hasil penelitian ini sejalan dengan hasil penelitian Reich et al. (2020) dengan hasil menunjukkan bahwa mayoritas responden (70\%) siap untuk memilih kelas online untuk mengelola kurikulum selama pandemi ini. Mayoritas siswa lebih suka menggunakan ponsel pintar untuk pembelajaran online. Menggunakan analisis konten, penelitian tersebut menemukan bahwa siswa lebih suka kelas yang direkam dengan kuis di akhir setiap kelas untuk meningkatkan efektivitas pembelajaran. Para siswa berpendapat bahwa fleksibilitas dan kenyamanan kelas online menjadikannya pilihan yang menarik, sedangkan masalah konektivitas broadband di daerah pedesaan menjadikannya tantangan bagi siswa untuk memanfaatkan inisiatif pembelajaran online. Hasil penelitian lain yang sejalan yaitu Ida Ayu (2020) dengan hasil penelitian bahwa pandemi virus corona telah menyebar di Indonesia dan mempengaruhi cara hidup orang Indonesia. Di sektor pendidikan, pandemi corona virus telah memaksa para guru untuk melakukan semua kegiatan belajar dari rumah. Oleh karena itu pembelajaran berbasis internet seluler dianggap sebagai cara pembelajaran yang efektif selama pandemi corona virus di Indonesia.

Hasil penelitian menjelaskan bahwa persepsi mahasiwa tentang pembelajaran online mengungkapkan bahwa pembelajaran online adalah solusi yang baik di tengah-tengah pandemi COVID-19. Mereka menganggap pembelajaran online sangat membantu di tengah pandemi. Dalam hal kendala dalam belajar secara online, mamasiswa juga memeberi respon bahwa kendala yang mereka hadapi cukup tinggi, adapun beberapa jenis kendala yang dihadapi seperti yaitu fasilitas belajar secara online yang tidak memadai, jaringan yang tidak memadai, membutuhkan biaya yang mahal, suasana belajar di rumah yang tidak kondusif, dan jadwal kuliah dilakukan oleh dosen dengan tidak teratur. Meskipun banyak kendala yang dihadapi mahasiswa, namun mahasiswa tidak pasrah dengan kaadaan tersebut, mereka bahkan lebih semangat untuk belajar mandiri. Hal ini dapat dilihat dari motivasi belajar mahasiswa yang berada pada kategori tinggi serta mahasiswa tidak hannya mengandalkan belajar tatap muka secara online, namun mahasiswa memiliki banyak cara dan metode belajar sendiri untuk menunjang pencapaian pembalajaran dalam satu semester yang telah menjadi kesepakatan pada awal perkuliahan melalaui kontrak perkuliahan yang diberikan oleh dosen.

Hasil penelitian ini juga sejalandengan hasil penelitian Longhurst et al. (2020) yang menjelaskan bahwa Pandemi Covid-19 telah mendorong perubahan tercepat ke pendidikan tinggi di 
seluruh dunia, yang diwajibkan oleh langkah-langkah jarak sosial yang mencegah pengajaran tatap muka. Hal ini menyebabkan peralihan jarak dekat ke pembelajaran jarak jauh (online) oleh institusi pendidikan tinggi. Anatomi pembelajaran online tersebut menghadapi beberapa tantangan diantaranya kesempatan untuk mengembangkan sumber daya online baru dan kesempatan untuk terlibat dalam kolaborasi akademik baru. Para akademisi menyebutkan tantangan yang dapat menempatkan batasan waktu pada kualitas dan efektivitas, terutama karena kurangnya paparan yang sempurna dalam pembelajaran.

\section{KESIMPULAN}

Dari hasil penelitian dan pembahasan, maka dapat ditarik simpulan bahwa meskipun kendala belajar yang dihadapi mahasiswa dalam masa pandemi cukup banyak, namun motivasi belajar mahasiswa berada pada kategori tinggi indikator hasrat dan keinginan ingin berhasil, adanya dorongan dan kebutuhan dalam belajar, adanya harapan atau cita-cita mahasiswa untuk masa depannya, mahasiswa belajar secara mandiri karena keinginannya sendiri, memiliki komitmen dalam belajar, memiliki inisiatif dalam belajar, dan memiliki sikap optimis dalam belajar; Selanjutnya cara belajar mahasiswa berada dimasa pandemi berada pada kategori baik dengan beberapa cara sendiri dalam bejar yaitu mengatur waktu belajar mandiri, mengulang bahan pelajaran, meluangkan waktu baca buku, meluangkan waktu membaca artikel dan referensi secara online, dan membuat ringkasan dari materi yang telah dibahas oleh dosen; dan kendalam belajar yang dihadapi mahasiswa dalam masa pandemi berada pada kategori tinggi. Adapun yang menjadi kendala dalam belajar online yaitu fasilitas belajar secara online yang tidak memadai, jaringan yang tidak memadai, membutuhkan biaya yang mahal, suasana belajar di rumah yang tidak kondusif, dan jadwal kuliah dilakukan oleh dosen dengan tidak teratur. Karena motivasi memiliki peran yang sangat penting dalam meningkatkan keaktifan mahasiswa dalam belajar, sehingga disarankan agar mahasiswa tetap menjaga dan terus meningkatkan motivasi dalam belajar, orang tua dan pemerintah hendaknya menyediakan fasilitas yang mamadai dalam pembelajaran secara online, mahasiswa agar meningkatkan kreativitasnya dalam belajar dimasa pandemi, serta dosen disarankan agar tetap menjalankan perkuliahan secara online sesuai jadwal kuliah dan menggunakan strategi pembelajaran yang efektif dan efesien. Selanjutnya kepada peneliti senajutnya agar dapat meneliti lebih jauh tentang strategi meningkatkan motivasi dan cara belajar mahasiswa.

\section{UCAPAN TERIMA KASIH}

Ucapan terima kasih yang sebesar-besarnya penulis sampaikan kepada Rektor Universitas Muhammadiyah Makassar yang senantiasa mendorong dan mensupport penulis dalam melakukan penelitian hingga sampai pada penerbitan artikel ini. Terima kasih juga kami sampaikan kepada responden yaitu mahasiswa Universitas Muhammadiyah Makassar yang bersedia bekerjasama dalam memberikan respon dan pengisian kusioner dalam penelitian ini.

\section{REFERENCES}

Amindoni, A. (2020). Virus corona: Gelombang PHK di tengah pandemi Covid-19 diperkirakan mencapai puncak bulan Juni, Kartu Prakerja dianggap tak efektif. https:// www.bbc.com/indonesia/indonesia-52218475. (Accessed on 2020-04-17).

Cao, C. and Meng, Q. (2019). Learning and Individual Di ff erences Exploring personality traits as predictors of English achievement and global competence among Chinese university students : English learning motivation. Learning and Individual Differences 77, 101814-101814. doi: https://doi.org/10.1016/j.lindif.2019.101814.

Collins, N. (2017). Motivation and self-regulated learn- ing: Theory, research, and applications. The Journal of Higher Education 80, 476-479. doi: https://doi.org/10. 1080/00221546.2009.11779027.

Djamarah, S. B. and Zain, A. (2010). Strategi Belajar Mengajar (Jakarta: PT. Rineka Cipta), 1-226.

Hamalik, O. (2011). Kurikulum dan Pembelajaran (Jakrta: Bumi Aksara).

Hidayati, Y. (2011). Pengaruh Cara Belajar Terhadap Prestasi Belajar Siswa Kelas Xii Jurusan Pemasaran Pada Mata Diklat Melaksanakan Proses Administrasi Transaksi Di Smk Taman Siswa Sumpiuh Tahun Pelajaran. Oikonomia: Jurnal Pendidikan Ekonomi 2, 36-41.

Jr, W. M., Glover, S., and Prawitt, D. (2017). Auditing \& Assurance Services: A Systematic Approach (Surabaya: Salemba 
Empat).

Kuan-ChungChen and Syh-JongJang (2010). Motivation in online learning: Testing a model of self-determination theory. Computers in Human Behavior 26, 741-752. doi: https://doi.org/10.1016/j.chb.2010.01.011.

Lim, D. H. (2014). Cross cultural differences in online learning motivation. Educational Media International 41, 163-175. doi: https://doi.org/10.1080/ 09523980410001685784.

Longhurst, G. J., Stone, D. M., Dulohery, K., Scully, D., Campbell, T., and Smith, C. F. (2020). Strength, Weakness, Opportunity, Threat (SWOT) Analysis of the Adaptations to Anatomical Education in the United Kingdom and Republic of Ireland in Response to the Covid-19 Pandemic. Anatomical Sciences Education 13, 301-311. doi: 10.1002/ase.1967.

Mukhtar (2013). Metode Penelitian Deskriftif Kualitatif (Jakarta: GP Press Group).

Purwanto, M. N. (2012). Prinsip-Prinsip dan Teknik Evaluasi Pengajaran (Bandung: PT Remaja Rosdakarya).

Putri, G. S. (2020). WHO Resmi Sebut Virus Corona Covid-19 sebagai Pandemi Global. https://www.kompas.com/sains/ $\mathrm{read} / 2020 / 03 / 12 / 083129823 /$ who-resmi-sebut-viruscorona- covid -19 - sebagai- pandemi- global?page $=$ all . (Accessed on 2020-03-11).

Reich, J., Buttimer, C., Fang, A., Hillaire, G., Hirsch, K., Larke, L., et al. (2020). Remote Learning Guidance from State Education Agencies During the COVID-19 Pandemic:A First Look (Chicago: TEACHING SYSTEMS LAB). doi: 10.35542/osf.io/437e2.

Sardiman, A. M. (2010). Interaksi dan Motivasi Belajar Mengajar (Depok: Rajawali Perss).
Sugihartono, Fathiyah, K. N., Harahap, F., SetIawati, F. A., and Nurhayati, S. R. (2007). Psikologi Pendidikan (Universitas Negeri Yogyakarta: UNY Press), 1-191.

Tanaka, M. (2013). Examining kanji learning motivation using self-determination theory. System 41, 804-816. doi: https://doi.org/10.1016/j.system.2013.08.004.

Uno, H. B. (2011). Teori Motivasi dan Pengukurannya: Analisis di Bidang Pendidikan (Jakarta: Bumi Aksara).

Walgito, B. (2014). Pengantar Psikologi Umum (Jakarta: Andi).

Wen, X. and Piao, M. (2020). Motivational profiles and learning experience across Chinese language proficiency levels. doi: 10.1016/j.system.2020.102216. https://dx.doi.org/10. 1016/j.system.2020.102216.

Conflict of Interest Statement: The authors declare that the research was conducted in the absence of any commercial or financial relationships that could be construed as a potential conflict of interest.

Copyright (c) 2020 Wahyuddin, Maharida, Jusriadi and Syafaruddin. This is an open-access article distributed under the terms of the Creative Commons Attribution License (CC BY). The use, distribution or reproduction in other forums is permitted, provided the original author(s) and the copyright owner(s) are credited and that the original publication in this journal is cited, in accordance with accepted academic practice. No use, distribution or reproduction is permitted which does not comply with these terms. 


\section{LIST OF TABLES}

1 Dasar Interpretasi Variabel Penelitian ～. . . . . . . . . . . . . . . . . . . 269

2 Kerakteristik Responden . . . . . . . . . . . . . . . . . . . . . . . . 270

3 Deskripsi Variabel Motivasi Belajar . . . . . . . . . . . . . . . . . . . 271

4 Deskripsi Variabel Cara Belajar . . . . . . . . . . . . . . . . . . . . . 272

5 Deskripsi Variabel Kendala Belajar . . . . . . . . . . . . . . . . . . . 273 


\section{TABLE 1 | Dasar Interpretasi Variabel Penelitian}

\begin{tabular}{lll}
\hline No & Nilai Skor & Interpretasi \\
1 & $1,00-1,80$ & Sangat Rendah/Tidak Penting \\
2 & $1,81-2,60$ & Rendah/Kurang Penting \\
3 & $2,61-3,40$ & Sedang/Cukup Penting \\
4 & $3,41-4,20$ & Tinggi/Penting \\
5 & $4,21-5,00$ & Sangat Tinggi/Sangat Penting \\
\hline
\end{tabular}




\section{TABLE 2 | Kerakteristik Responden}

\begin{tabular}{llll}
\hline No & Kerakteristik Responden & Frekuensi & Persentase \% \\
1 & Jenis Kelamin & 188 & 25,97 \\
& Laki-Laki & 536 & 74,03 \\
& Peremuan & & \\
& Semester & 212 & 29,28 \\
& II & 291 & 40,19 \\
& IV & 160 & 22,10 \\
& VI & 41 & 5,66 \\
& VIII & 20 & 2,76 \\
& $>$ VIII & \\
& & \\
& & \\
\end{tabular}


TABLE 3 | Deskripsi Variabel Motivasi Belajar

\begin{tabular}{lll}
\hline Indikator & Mean & Kategori \\
X1.1. Hasrat dan keinginan ingin berhasil & 4,15 & Tinggi \\
X1.2. Adanya dorongan dan kebutuhan dalam & 4,04 & Tinggi \\
belajar & & \\
X1.3. Adanya harapan atau cita-cita masa depan & 4,51 & Tinggi \\
X1.4. Belajar mandiri karena keinginannya sendiri & 4,05 & Tinggi \\
X1.5. Memiliki komitmen dalam belajar & 4,08 & Tinggi \\
X1.6. Memiliki inisiatif dalam belajar & 3,98 & Tinggi \\
X1.7. Memiliki sikap optimis dalam belajar & 3,98 & Tinggi \\
Mean Variabel Motivasi Belajar & 4,11 & Tinggi \\
\hline
\end{tabular}


TABLE 4 | Deskripsi Variabel Cara Belajar

\begin{tabular}{lll}
\hline Indikator & Mean & Kategori \\
X2.1. Mengatur waktu belajar mandiri & 3,62 & Tinggi \\
X2.2. Mengulang bahan pelajaran & 3,54 & Tinggi \\
X2.3. Meluangkan waktu baca buku & 3,32 & Tinggi \\
$\begin{array}{l}\text { X2.4. Meluangkan waktu membaca artikel \& refer- } \\
\text { ensi secara online }\end{array}$ & 3,56 & Tinggi \\
$\begin{array}{l}\text { X2.5. Membuat ringkasan/khtisar dari materi yang } \\
\text { telah dibahas oleh dosen }\end{array}$ & 3,52 & Tinggi \\
Mean Variabel Cara Belajar & 3,51 & Tinggi \\
\hline
\end{tabular}


TABLE 5 | Deskripsi Variabel Kendala Belajar

Indikator

X3.1. Fasilitas belajar secara online yang tidak

memadai

X3.2. Pembelajaran online terkendala dengan jaringan yang tidak memadai

X3.3. Pembelajaran online membutuhkan biaya yang mahal

X3.4. Suasana belajar di rumah yang tidak kondusif

X3.5. Jadwal kuliah dilakukan oleh dosen dengan tidak teratur

Mean Variabel Kendala Belajar

\begin{tabular}{ll}
$\begin{array}{ll}\text { Mean } \\
3,13\end{array}$ & $\begin{array}{l}\text { Kategori } \\
\text { Tinggi }\end{array}$ \\
4,20 & Tinggi \\
4,17 & Tinggi \\
3,89 & Tinggi \\
3,09 & Tinggi \\
3,69 & Tinggi \\
\hline
\end{tabular}

